\title{
“An artist, first and foremost”. An Interview with Sara Baume
}

\author{
Margarita Estévez-Saá \\ Universidade de Santiago de Compostela, Spain
}

Copyright (c) 2020 by Margarita Estévez-Saá. This text may be archived and redistributed both in electronic form and in hard copy, provided that the author and journal are properly cited and no fee is charged for access.

\begin{abstract}
Sara Baume has become one of most brilliant recent voices in the literary and artistic panorama of contemporary Ireland. She has managed to combine in a unique way an already established career as a writer with her vast knowledge of art and her own artistic projects. Baume has written two unanimously critically acclaimed novels, spill simmer falter wither (2015) and A Line Made by Walking (2017) and a handful of short stories which have been published in prestigious literary magazines and collections such as The Stinging Fly, Granta, The Moth, The Dublin Review, or The Davy Byrnes Collection. More recently, she published Handiwork (2020), a most intimate account of her life, interests and projects as a writer and as an artist, as well as a deeply felt personal homage to the figure of her dead father. In the present interview, the writer comments on the contemporary panorama of Irish literature, on the social and economic changes that have taken place recently in her native country, and on the two languages between which she has always felt caught, the one that goes down on paper and the one that goes down in small painted objects. These two languages have been put at the service of one of the most obvious and recurrent interests of the writer, her endless fascination for and deep concern with nature and animals.
\end{abstract}

Key Words. Sara Baume, Irish literature, Contemporary Ireland, Nature, Non-human Animal Representation.

Resumen. La escritora Sara Baume se ha convertido en una de las voces más brillantes del actual panorama artístico y literario en Irlanda. Baume ha conseguido combinar de forma única su ya consolidada carrera como escritora con sus ingentes conocimientos sobre arte y sus propios proyectos artísticos. Baume ha escrito dos novelas unánimemente aplaudidas por la crítica, spill simmer falter wither (2015) y A Line Made by Walking (2017); y un considerable número de relatos cortos que han sido publicados en prestigiosas revistas y colecciones literarias como The Stinging Fly, Granta, The Moth, The Dublin Review, o The Davy Byrnes Collection. Más recientemente ha publicado Handiwork (2020), un íntimo testimonio de su vida, intereses y proyectos como escritora y como artista, a la vez que un sentido y personal homenaje a la figura de su padre fallecido. En la presente entrevista, la escritora comenta el 
panorama actual de la literatura irlandesa, los cambios sociales y económicos que han tenido lugar recientemente en su país, y los dos lenguajes entre los que siempre se ha sentido atrapada, el que vierte en el papel y el que transforma en pequeñas series de miniaturas. Sara Baume ha puesto estos dos lenguajes al servicio de uno de sus intereses más obvios y recurrentes, su eterna fascinación y preocupación por la naturaleza y los animales.

Palabras clave. Sara Baume, literatura irlandesa, Irlanda contemporánea, naturaleza, representación de animales no humanos.

Irish writer Sara Baume has become one of the most interesting young voices in the already brilliant panorama of contemporary Irish writing. Her published fiction to date, two novels, a memoir and a handful of short stories, deploy most of the features which distinguish the current Irish literary scene: updated and daring topics and a formal brilliance that illustrates the seemingly endless capacity of Irish writers for playing with conventional literary genres and offering a renewed aesthetics.

Baume, born in 1984, was raised and is settled nowadays in County Cork, after having studied Fine Art at Dun Laoghaire College of Art, and Design and Creative Writing at Trinity College, Dublin. So far, she has published two critically acclaimed novels, spill simmer falter wither (2015) and A Line Made by Walking (2017), two fragmented narratives which deploy the idiosyncratic unease of Irish writers with the novel conceived as a long straightforward coherent narrative oriented towards a conclusion, and their endless preference for renewal and experimentation with the genre.

More recently, Sara Baume has published a highly lyrical and intimate non-fiction narrative, Handiwork (2020), a text in which the author reflects on the artistic process, including a description of the spaces devoted to her art, that she calls her "house of industry"; offers an account of the most diverse materials collected by the artist and her partner for their artistic enterprises; and even explains a specific art project, a series of model figures of tiny handmade birds which is illustrated with photographs interspersed in the book. Handiwork, written in the aftermath of her father's death, is also Baume's homage to her progenitor, whose entrepreneurship she melancholically recalls, and that provides the writer with a unique opportunity to include sound meditations on memory, grief, time, nature and art.

Baume is also a brilliant storyteller, and her short fiction has been included in prestigious magazines such as Granta, The Stinging Fly, The Moth, The Dublin Review, or The Davy Byrnes Collection, among others.

Baume's protagonists in both her novels and short stories are solitary people, misfits of our society, mostly representatives of those human beings who find it difficult to adapt themselves to contemporary standards and conventions and who look for different ways of living or rather try to establish alternative communities of life in Cary Wolfe's terminology (Barcz 250). Similarly to the case of her novels where we find a middle-aged man who has remained isolated from his community since early childhood and who establishes his most successful affective relationship with a one-eyed dog (spill simmer falter wither), or a young aspiring woman artist suffering from depression who goes to live at her grandmother's rural cottage (A Line Made by Walking), the characters in her short stories are also loners recurrently represented in natural environments where non-human beings acquire particular relevance to the point of becoming protagonists of some of her narratives ("Fifty Year Winter", "Solesearcher1”, “Green, Mud, Gold” or “The Infinite Goldfish”).

Sara Baume visited Santiago de Compostela in 2018, coinciding with the celebration of the XVII International Conference of the Spanish Association for Irish Studies (AEDEI) organized by the Universidade of Santiago de Compostela, in which Baume participated as a 
Plenary Speaker. The beginning of this interview took place while Sara was in Santiago, and it was later on updated by mail thanks to the generosity of the author throughout 2019 and early 2020. ${ }^{1}$

Margarita Estévez-Saá: Eimear McBride, Claire Kilroy, Lisa McInerney, Caitriona Lally, and you, among many other new voices, are becoming representative of contemporary Irish letters. Do you feel as belonging to a particularly brilliant young generation of Irish women writers who are demonstrating that women have something novel to offer both from a thematic and a formal point of view? In this sense, I inevitably recall Eve Patten's words when in 1996 she wrote that "women's writing in Ireland is enduring an abnormal long adolescence” (7), as well as Nuala O'Faolain's similar statement from 1985. They were basically referring to the confessional realism that, according to them, had prevailed in Irish women's fiction. I have always found these commentaries deeply unfair, taking into account that the reason for their critique was probably that women's contribution to Irish literature had not been properly assessed at that moment. Notwithstanding, your generation is clearly deploying a seemingly inexhaustible, almost unprecedented technical brilliancy.

Sara Baume: Without doubt, there has been a new kind of emphasis placed upon Irish women writers in recent years, and not at all just the contemporary ones but those of generations past who have been chronically under-celebrated. Maybe this started with The Long Gaze Back, edited by Sinead Gleeson in 2015, and with small presses like Tramp and The Stinging Fly reissuing the works of writers like Dorothy Macardle and Maeve Brennan. This reflects what has been happening globally, of course, with the \#MeToo campaign and this new wave of feminism, and very specifically here in Ireland, with the abortion referendum in 2018.

Personally, I don't feel like I was raised in a country that was oppressing women though I know I was, to a degree. I never felt under pressure to maintain the religion I was born into (Roman Catholicism), to marry and have kids, to pursue a stable, viable career... and probably this is significant. I was free to grow up - a little bit in the eighties, mostly in the nineties and noughties - with different, higher expectations than the Irish women of earlier generations (and I suppose that's what I was writing about in A Line Made by Walking - a young woman who has been raised to expect much from life, and is bitterly disappointed, and has to figure out a way to cope with that).

So are we a particularly brilliant generation or it is just that we are abruptly being paid attention to and assessed, just as you suggested...? I guess only time will tell...

What's interesting about the quote is that 'confessional realism' is definitely having a moment - perhaps especially in the case of Irish women - and yet I feel it is doing something fresh, something much more mature and literary than was perhaps the case in the past, say in the examples, just this year, of Sinead Gleeson's Constellations and The Scar by Mary Cregan.

MES: If we accept that there is a new generation of Irish writers, and I'd also include names of male authors such as Donal Ryan, Paul Murray or Kevin Barry, I would say that your work seems to share some features. Formally speaking, all of you are demonstrating the inexhaustible capacity of the Irish to offer something new, to revise the genres of the novel and the short story, and to keep on deploying a particularly Irish outstanding ability to play with language and form. With regards to the topics I would say that if, from James Joyce onwards average men and women began to be represented in fiction, we can detect now a deep concern for the physically and mentally disabled, for representing the weakest, the alienated, the most fragile members of our society who have 
been neglected, silenced, and ignored both in culture and in society. Is this, in your case, any sort of ethical compromise as an artist?

SB: Irish fiction has always been full of oddballs - Bloom, Molloy, Sweeney - but perhaps there is something to be made of the idea that we are becoming more sympathetic toward our fictional oddballs...

Over and over again, I see how artists (in a general sense) become artists because they feel or have felt 'othered' by their peers in some form or another. This can be because of something huge - like illness, bereavement, estrangement, or it can be because of something slight, as in my own case. I've always felt a bit 'othered' because my dad was a divorced Englishman, and I was born in the UK. I was raised Roman Catholic in a rural place, a small community, and I always knew I was - just slightly - different to my peers because of my dad, of my vaguely-English accent, of my foreign surname. This seems very slight now, but I wholly believe it was what set me on an artistic path.

When I started writing spill simmer in my late twenties, I had just moved to a small seaside village after several years of living in Dublin. Suddenly I felt 'othered' all over again, conspicuous, and in the novel I was telling the story of that experience by means of a different story, a different experience - if that makes sense? I felt very lonely and a bit ostracized and I created Ray as a symbol, as an extremity, of my own condition.

I see this played out in fiction all the time - I think it is almost certainly where the fiction I admire the most comes from.

In a specifically Irish context, so much has changed here in the last thirty years or so. The Catholic Church abuse scandals which started to break in the nineties coincided with a wave of liberalism - we became stealthily so much more open to global influence and this has all brought about a decisive swing toward skepticism and a championing of the disadvantaged and 'othered' - the gay marriage referendum in 2015 being a prime example.

Joyce became a writer to rebel against the Catholic Church, or rather, that is how I always think of him. And perhaps that repeats itself to some degree or another, in every Irish writer since...!

MES: Joseph O'Connor, Eimear McBride, Anne Enright, all of them have praised your novels and short stories. Overwhelming, isn't it? You wrote a most illuminating piece for The Irish Times, entitled "Cautionary Tale about What It Costs to Be a Writer" in 2015, which I would recommend to any aspiring artist, as well as to young men and women seeking for a job or a profession. After your literary success, do you still subscribe the fears, anxieties and pressures exposed in that essay?

SB: Yes! And I should probably write a follow-up to that article now, describing how the fears, anxieties and pressures never disappear, but simply transform. Anyone pursuing a career in the arts should be told on Day One that they are subscribing to a future dogged by uncertainty...but that this can be a wonderful, liberating thing too.

I'm 36 now and it might be quite nice to have a little more security, to own my roof, for example, but I also love the idea that my life is not terribly well fixed down - that I have no idea what form I'll be working in, or where I'll be living, or whether or not I'll be remotely successful - in ten or even five years time.

And I've never believed the hype! I feel like I still have so much to learn - that I've barely even started yet...

MES: I have referred to a new young generation of successful Irish writers who are attaining international acclaim. Most of you entered the literary scene after the collapse 
of the so-called Celtic Tiger, precisely during the years of economic recession and shortage. I detect a generalized preference for the representation of outcasts, losers, the misfits of our society. Nevertheless, all of you have managed to succeed precisely under the most adverse circumstances. We have a saying in Spanish, "la necesidad agudiza el ingenio", which can be roughly translated as "necessity is the mother of invention". Would you say that the Irish have been historically more creative at times of crises, and was this creativity somehow rewarded by the efforts of small independent publishing houses such as Tramp Press?

SB: I think this is very true - something definitely arose out of the economic depression of the eighties with writers like Roddy Doyle, Anne Enright and Colm Tóibín, and then it seems to have happened over again with my generation.

For me, the recession had a very significant influence. I was a teenager and then a college student during the Celtic Tiger, and that gave me high expectations for the future. When the crash occurred in 2008, I was working in art galleries in Dublin, contributing art criticism to journals, thinking about doing a Master in creative writing. By 2011, I'd finished my Master but I was finding it hard to find steady gallery work and two of the journals I'd been writing for had gone out of print. My partner (who is also an artist) and I were struggling to afford the city's rising rents and so we moved to the countryside, way down south - to a shabby little house in the seaside village I mentioned earlier. We lived mostly on the dole then, with a handful of crappy part-time jobs in-between, for five years, and it was during those years that both my novels were written. It was a hard, bleak period but it was also very simple and joyful at times, and I'm so grateful for that now. It sounds perhaps strange to say but if it wasn't for the recession and all the opportunities that it removed from my life I doubt if I'd have felt the freedom, and perhaps also the despair, to pursue my writing. I certainly would never have finished a novel, let alone a second.

I think something similar happened with Tramp, who at the time felt they might just as well set up their own indie press - they had nothing to lose. I only sent the manuscript of spill simmer out to a couple of small presses and Tramp were the only one to respond, and it was only after it had been published that I signed with a literary agent and the rights sold on to different territories.

MES: After reading your two very successful novels, as well as some of the short stories that you've already published ("Solesearcher1", "Fifty Year Winter", "The Infinite Goldfish”), there are a series of recurrent concerns that can be easily identified in most of your works, such as human isolation, problems of communication, and, above all, a most powerful and detailed observation of nature and a deep interest in the connections between the human and the non-human environment ("Green, Mud, Gold"), as well as between human and non-human animals (spill simmer falter wither, "Fifty Year Winter", “The Infinite Goldfish”). Would you consider yourself as a nature writer?

SB: I love it when other people describe me as a nature writer, but I wouldn't use the term myself...I suppose because I feel I don't have any particular expertise, and because what I'm writing is essentially fiction... always full of lies! The natural world is an enormous part of my daily experience - every day and in all weathers I walk the fields, swim in the sea, feed the birds and very often eat the fish my partner has caught, and so because what I write is always some kind of a reconfiguration of my daily experience, the natural world is just there...because....it is just...there.

To be completely honest, whatever form I am working in, I am always trying to make a piece of art, first and foremost. Though I have an endless fascination for nature, I wouldn't say 
that its description is my primary focus, though I realize that I do indeed devote an awful lot of sentences to exactly that...

MES: Nature, the land, the environment, and non-human animals are more than a mere question of aesthetics for Ireland and for the Irish. The land has been, as Terry Eagleton argued, "an economic and political category and an ethical one" (Heathcliff and the Great Hunger, 4). How do you think that the years of economic welfare, the so-called Celtic Tiger years, have affected Ireland from an ecological perspective?

SB: The Celtic Tiger definitely hurt Ireland from an ecological point of view - and on a societal level it brought out a nasty side of people's nature, which impacted on the environment in turn - an obsession with property, and with ownership and one-upmanship, with wealth and appearances.

Both my novels are full of subtle jibes - but this is something which has perhaps influenced my art practice more directly than my writing. The article in Elementum. A Journal of Nature \& Story that I sent you is probably the best answer for this question...

MES: Sara Baume's article for Elementum was published in 2019 under the title "Talismans and Tombstones" and it includes her reflections on the changes in the Irish landscape provoked by the years of affluence and prosperity and images of her own ironic artistic response, a miniature series of "figurines" entitled "Talismans" that she describes as "a ten-metre-long horizon line of miniature houses, each carved from plaster to the rough scale of a cottage souvenir, but in the style of a contemporary rural dwelling -large, asymmetrical and endowed with an abundance of unnecessary appendages" (80). Baume explains that she was inspired by the changes that she detected in the parish where she had grown up when she returned to it after her university years and that she defines as "a defilement of the landscape of the idyll of my childhood" (76). She became deeply interested in the topic and searched for information about indigenous architecture in Ireland in books and articles she came across, such as Irish Cottages (1990) and The Irish Cottage (2017), as well as by her visit to the exhibition entitled "Country Life" held at the National Museum of Ireland in County Mayo that she visited in summer 2018. In the article she describes her objective: "The idea was to draw a contrast between the grandiosity of the monster mansions and my choice of coarse, everyday materials -the intention being to invent an updated, and deeply cynical, souvenir" (76); and she deploys the concerns that guided her artistic project: "It was a year of rising rents, rising house prices, rising homelessness -and I had spent it shaping talismans as if by this means I might interpret my anxieties about the extinction of landscapes and the scarcity of sustainable homes; as if these miniatures and the process of their making might symbolize an attempt to protect against the future as well as to preserve the past” (81).

MES: spill simmer falter wither is an extremely intimate narrative in which a middle-aged man, isolated from society since childhood, addresses the dog he has rescued from a kennel, One Eye, thus named since the animal lost one of his eyes in the past. I've read that you thought first about adopting the perspective of the dog, that afterwards you pondered the possibility of a first-person narrator, and that, finally, and in my opinion very successfully, opted for a second-person narrator, so that the man addresses his dog. From an ecocritical perspective, I really believe that yours was the wisest choice. Some ecocritics, in particular posthumanist animal studies specialists, have sensibly warned us against "speaking for nature" (Murphy, Gruen). This does not imply that there is no possible communication between humans and the non-human environment, including 
animals, but that we should not pretend to speak for nature or for animals. Ray, the protagonist of your first novel, illustrates perfectly well how the possibility of communication exists between humans and animals without necessarily trying to impose our views and our voices, and silencing those of the non-human animal. Let me exemplify with some passages from your novel how you have managed to convey this idea of representing the animal as a sentient creature capable of experiencing joy, pain, fear, fury:

What must I look like through your lonely peephole? (12)

Sometimes I see the sadness in you, the same sadness that's in me. It's in the way you sigh and stare and hang your head. It's in the way you never wholly let your guard down and take the world I've given you for granted. (42)

I wonder: what are the things that trouble you? (160)

Ray recalls all the information that we have about the world of animals, which he has learned from books or from the radio programmes that he listens to. Nevertheless, rather than imposing an anthropocentric account of animal life, he keeps on respectfully acknowledging his limited knowledge of animal life, which on the other hand, does not prevent him from establishing a more than fluid communication with his animal companion. Are you aware of the alternative perspective you are opening for a new way of representing non-human animals in fiction?

SB: While I struggled for the voice at first, when it finally came it felt very logical and natural - I realized that all I had to do, really, was just listen to myself talking to my dog, and then to read his reactions. Around this time, my partner was working part-time and I was spending a lot of time alone with the dog, just the two of us. I couldn't bear being in the house for long hours so I'd drive around with him sitting up beside me in the passenger seat and we'd go for walks or just hang around on windswept beaches or eat biscuits in the car and I'd talk away to him as if he could understand - I was thinking aloud really, talking nonsense to myself, (as a means of comfort) and this was where Ray's voice finally emerged from.

While I was writing spill simmer I made a point of reading 'dog novels' and I wrote an essay for The Stinging Fly magazine, published early in 2015 to coincide with the novel's publication, entitled "Eat Or Be Eaten" and subtitled “An Incomplete Survey of Literary Dogs". I think that what I was really trying to do with this essay and its research was to align One Eye with the canine characters of Virginia Woolf and Mikhail Bulgakov and Kafka - to get as far away from Old Yeller and Lassie as possible!

MES: I've read in an interview (I think it was for the TLS) that if you were to change or delete anything you had written, you'd probably skip the dream sequences from spill simmer falter wither. Which passages were you referring to, since I believe that Ray's dreams contribute to enrich the characterization of his mental life?

SB: I agree...now. In the very first review of the novel - by Joseph O' Connor in The Irish Times - he questioned the inclusion of the dream sequences. It was 99\% a tremendous review and this was the only small criticism but it really burned me - the acute sensitivity of the debut novelist!

Now, with the benefit of hindsight, I stand over the dream sequences. My intention was to show how Ray becomes increasingly, deeply attached to One Eye - that he is thinking and worrying about his dog so much that he starts to dream about him - he starts to dream dreams in which he becomes his dog. 
MES: Your novels seem to be addressed to a reader who is compelled to actively engage and participate rather than simply passively read your texts.

Let me describe to you my experience. In the case of spill simmer falter wither, it is almost inevitable to share Ray's constant doubts and reflections on how much we know about animal life, the possibilities and limits of our human understanding of animals' feelings and their ability to establish communication. More clearly even, in A Line Made by Walking the constant references that Frankie, the protagonist, makes to art, led me to constantly check on the internet the art works mentioned so as to more fully understand how these allusions contributed to understanding Frankie's flow of thought, as well as to fully grasp her acute reflections on art.

On the other hand, I think it is perfectly possible to read and enjoy your novels in a more passive, detached, less-involved way. Would you agree that the two narratives offer different levels of participation depending on your readers' mood and disposition?

SB: I hope so. This makes me incredibly happy.

My background is not, at any stage, the study of literature - in college, I was rarely required to sit still and listen, to silently study. Instead, I quickly became accustomed to being in a studio situation, always working with my hands, very actively searching and collecting, and then engaging and collaborating with others. At the same time, of course, there was cinema, music, books. I guess that mode of working is still my default...in spite of so many mornings sitting quietly at the desk! By the afternoons I'm usually, irresistibly, on my feet, and in my art practice, I'm constantly touching, feeling, spinning things around in the light...fidgeting!

I hadn't given this much thought, and it's exciting to think that my mode of working might travel through the books, that it might infect the reader somehow...

MES: I want to sincerely congratulate you on your exceptional characterization of protagonists such as Ray (spill simmer falter wither) or Frankie (A Line Made by Walking) with whom readers not only sympathize but even identify. It is difficult not to share, for instance, some of Ray's fears, and any of us have more than probably shared his reluctance to socialisation on several occasions; similarly, twenty-five year-old Frankie deploys the doubts, uncertainties and sense of purposelessness that many of us have experienced at that age, or at a given moment in our lives. Some reviewers have referred to your protagonists as representations of disability in fiction; notwithstanding, would you agree that rather than disabled characters, they perfectly illustrate the fragility of our human condition that all of us can experience at certain moments in our lives?

SB: I feel honored that you have studied my work so closely, and I've learned a tremendous amount from engaging with your questions. I think that's a gorgeous way of putting it: that I am trying to illustrate the frailty of the human condition - frailty is something I am fascinated by. I've never mentioned this before, probably because it seems rather dark and morbid, but I tend to seek out artworks, books, films which dwell on madness, illness, depression - I'm haunted by the thin line we all tread in the course of our very ordinary lives. I am also terrified of experiencing these things personally - I worry constantly about falling ill and not being able to cope. Perhaps reading and writing about frailty in the way that I do is a subconscious means of staving if off...?

If I now understand it well enough, then I will be safe from it. Does that make sense?

MES: It does, of course, it certainly makes a lot of sense. Continuing with the process of characterization of your protagonists, you have said elsewhere that there are some roughly autobiographical aspects in A Line Made by Walking, and that your inspiration 
for Ray came from a man who lived nearby your village. You have equally managed to successfully portray the inner world of a middle-aged man who has been living apart from society since infancy, and that of a twenty-five-year-old aspiring woman artist suffering from depression. I imagine that your second novel was easier to write than the first one, since you are also a young woman with a degree in art. Was this the case?

SB: Each novel was, as I've already sort-of mentioned, drawn from my daily experience at a different stage of life - I suppose I am following Joyce in this way.

A Line stemmed from a creative non-fiction essay I wrote for a course as part of my Master's degree - in a very abridged form, it was a precursor to spill simmer, and it was easier to write, but mainly because I knew for sure that it would be published; I even had a deadline and so I felt validated, and so the process of writing my second novel was not so thwarted by disillusion as the process of writing my first had been.

MES: How do you see your future as a writer? Would you continue to combine writing short stories and novels? Is it not difficult to write a third novel after having published two masterpieces such as spill simmer falter wither and A Line Made by Walking?

SB: I can answer this with a tiny bit of breaking news...my third book will be published by Tramp Press in spring 2020 - it's very short, just a long essay, really, and it will be shot through with photographs of a parallel sculptural project. The title is Handiwork and just this morning I described it for the press release as "this little book is a love-child of my art and writing practices, or a by-product of novels past and coming. It's about the connection between handicraft and bird migration, as well as simply the account of a year spent making hundreds of small, painted objects in an isolated house."

And now I am working on my third novel, which will also be incredibly short.

MES: Handiwork was in fact published during the period of confinement in 2020. Therefore, I opted for updating the interview with Sara Baume, appealing to her generosity and sending her three further questions that we reproduce in the following lines. The first question refers inevitably to the pandemic and the period of confinement. Your readers would certainly like to know how this unexpected circumstance has affected you, as well as your work and your plans. What is your view about this tragedy and about its consequences for our society?

SB: Here in Ireland, our lockdown came into effect at the end of March. Handiwork was due to be published on the $26^{\text {th }}$, and so I had an awful lot of events scheduled that were either cancelled or went online. In a practical sense, my daily routine changed very little. I have missed family and close friends, and it has been boring, but these are my only complaints. I feel very lucky to live where I do, already isolated from other people and close to the sea. It has also been an unusually productive period, without any of the interruptions that come about in the course of normal life. I'm almost finished my next novel now, and I've had a handful of commissions that came about directly as a result of the pandemic. ${ }^{2}$ The most difficult thing for me, to be completely honest, will be emerging and having to learn to be a public person again. It seems to come very naturally to my partner and I to live reclusively.

MES: Focusing now on Handiwork, a work in which birds are protagonists - both the vast types of birds named and described, as well as the miniatures whose photographs are included-, you refer to your partner and you and say "He is fish, and I am birds" 
(138), why did you choose birds on this precise occasion because you had already written beautifully about many other animals (dogs, fishes, dead animals)?

SB: I started to become very interested in birds around the beginning of 2018. I can't say precisely why; I mean, other than the obvious, birds are such strange creatures, so unattainable, magic. Once you start birdwatching and learning to identify different species, there's no going back! Maybe it has something to do with the fact that birds are everywhere, every time you leave the house, even in the middle of a city. And often they have travelled so far; they are like little missives sent from far flung parts of the planet. Nowadays I never go for a walk without my pocket binoculars.

MES: Finally, and again in relation to the importance of nature and animals in your works, it really surprised me what you say on page 171, "I flail for small absolutions, but I am Audubon -caring chiefly and obsessively not about nature but the accuracy and beauty of its depiction- not the living world, but its lifeless replication". Readers familiarized with your texts (and Handiwork is no exception) would not exactly agree with this statement. We can understand your earnest efforts at replicating nature in, for instance, the model bird series; but in your novels, short stories as well as in Handiwork, you've gone further than that, deploying a sincere care and concern about nature. In Handiwork, for instance, you certainly conceive and delve upon birds as living and sentient creatures, and you deploy a vast knowledge about their types, names, feeding habits, migratory movements, creaturely gaze, communication practices, etc. To a certain extent, and I'd like you to comment on this, I'd say that your identification with Audubon applies to one of your languages - "the one that you cannot speak"-, but is not fair to the one that you can speak and that "goes on the paper"; a language that, to a good extent, you are putting at the service of living nature.

SB: This is a really interesting observation; it touches on something I have yet to fully figure out for myself. Certainly I adore the natural world, and I have sincere, profound fears for its decline and death, and I would like to be of some use when it comes to protecting it, to spread knowledge at the very least. But I see myself as an artist, first and foremost. Evidently I don't care enough about the natural world to give up all my projects and devote myself to conservation. I learn the name of plant species, for example, so that I can incorporate them into prose. I'll remember the ones that have a lovely sound and shun the ones that don't. Do I make art about the things I care about ... or do I care about things because I can make art out of them? I'm not entirely sure.

\footnotetext{
Notes

${ }^{1}$ I wish to acknowledge the grant PGC2018-093545-B-I00 MCIU / AEI / FEDER, UE for the research project "The Animal Trope"

${ }^{2}$ Sara Baume sent me information about two instances of the commissions received during the Pandemic. Thus, she participated in the Glucksman Museum project "Home from Home: Irish artists respond to COVID-19 restrictions", with the composition of a series of miniatures of the house where she lives that were to be accompanied by a text "that weighs the banality of ornament-making against the backdrop of epic catastrophe" (http://www.glucksman.org/events/home-sara-baume).

Similarly, Baume proposed the text "so sick and tired" that hangs publicly on the front façade of the National Sculpture Factory's building from Sunday 21 June, and that was commissioned by the National Sculpture Factory on occasion of the Cork Festival's Midsummer Moments. Baume explains her text as follows: "This fragment of a sentence was drawn from a series of notes I made throughout the spring and early summer of 2020. I have lived my entire adult life under certain constraints, practically all of them self-imposed. This line is trying to express the
} 
longing for some dramatic kind of deliverance from my boring, consoling habits.” (http://nationalsculpturefactory.com/so-sick-and-tired/)

\section{Works Cited}

Barcz, Anna. "Posthumanism and Its Animal Voices in Literature”. Teksty Drugie 1 (2015): 248-268.

Baume, Sara. A Line Made by Walking. London: Heinemann, 2017.

. Handiwork. Dublin: Tramp Press, 2020.

. spill simmer falter wither. Dublin: Tramp Press, 2015.

"Eat Or Be Eaten: An Incomplete Survey of Literary Dogs”. The Stinging Fly 30. 2

(Spring 2015). 22 May 2018. https://stingingfly.org/2015/02/01/eat-eaten-incompletesurvey-literary-dogs/

. "Fifty Year Winter”. The Stinging Fly 26. 2 (Winter 2013-14): 53-57. 17 June 2020. https://stingingfly.org/2013/11/01/fifty-year-winter/

. “Green, Mud, Gold”. Granta 135 (Spring 2016): 90-99.

. "Sara Baume's cautionary tale about what it costs to be a writer". The Irish Times. 5

February 2015.

. “Solesearcher1”. Davy Byrnes Stories 2014. Dublin: The Stinging Fly Press, 2014. 1-18.

. "Talismans and Tombstones: On Cottages Countryside and Tiny Constructions". Elementum. A Journal on Nature \& Story. Edition Five "Hearth”, 2019.

. “The Infinite Goldfish”. Granta. 5 March 2018. 22 May 2018. https://granta.com/infinite-goldfish-baume/

Cregan, Mary. The Scar. Dublin: The Lilliput Press, 2019.

Eagleton, Terry. Heathcliff and the Great Hunger: Essays on Irish Culture. London \& New York: Verso, 1995.

Gleeson, Sinead. Constellations. London: Picador, 2019.

. The Long Gaze Back. An Anthology of Irish Women Writers. Ireland: New Island Books, 2015.

Gruen, Lori. "Revaluing Nature”. Ecofeminism: Women, Culture, Nature. Ed. Karen J. Warren. Indiana: Indiana UP, 1977. 356-74.

Mcgarry, Marion. The Irish Cottage: History, Culture and Design. Dublin: Orpen Press, 2017.

Murphy, Patrick D. "Rethinking the Relations of Nature, Culture, Agency". Environmental Values 1. 4 (1992): 311-322.

O’Connor, Joseph. "Spill simmer falter wither, by Sara Baume: Greatness already Evident”. $\begin{array}{lllllll}\text { The Irish } & 22 & \text { Times. } & 7 & \text { February } & 2017 .\end{array}$ https://www.irishtimes.com/culture/books/spill-simmer-falter-wither-by-sara-baumegreatness-already-evident-1.2094028

O’Faolain, Nuala. "Irish Women and Writing in Modern Ireland”. Irish Women: Image and Achievement. Ed. Eiléan Ní Chilleanáin. Dublin: Arlen, 1985. 127-135.

Patten, Eve. "Women and Fiction 1985-1990”. Krino 1986-1996: An Anthology of Modern Irish Writing. Ed. Gerald Dawe and Jonathan Williams. Dublin: Gill \& Macmillan, 1996. 116.

Shaffrey, Marua and Walter Pfeiffer. Irish Cottages. Foreword by Alice Taylor. London: Weindenfeld \& Nicolson, 1990.

Received: 4 August 2020 Revised version accepted: 4 September 2020 
Margarita Estévez-Saá is Senior Lecturer of English and American Literature at the Universidade de Santiago de Compostela. Her research interests include the work of James Joyce and, more recently, contemporary Irish fiction by women. She has published essays in which she studies the topic of immigration in recent Irish fiction, such as "Antidotes to Celtic Tiger Ireland in Contemporary Irish Fiction: Anne Haverty's The Free and the Easy and Éillís Ní Dhuibne's Fox, Swallow, Scarecrow” (2010) and "Immigration in Celtic Tiger and postCeltic Tiger Novels” (2013). She has also read contemporary novels in English from a transcultural perspective in "Trauma and Transculturalism in Contemporary Fictional Memories of the 9/11 Terrorist Attacks” (2016) and “'Us returniks': Transcultural Atlantic Exchanges in Mary Rose Callaghan's and Elizabeth Wassell’s Novels” (2018). More recently, she has co-edited with María Jesús Lorenzo-Modia the volume The Ethics and Aesthetics of Eco-caring: Contemporary Debates on Ecofeminism(s) (Routledge, 2019).

margarita.estevez.saa@usc.es 